\title{
Photosynthetic production of enantioselective biocatalysts
}

Maik Bartsch', Sarah K Gassmeyer ${ }^{1}$, Katharina Köninger ${ }^{1}$, Kosuke Igarashi², Pasqual Liauw ${ }^{3}$, Nina Dyczmons-Nowaczyk ${ }^{3}$, Kenji Miyamoto ${ }^{2}$, Marc M Nowaczyk ${ }^{2^{*}}$ and Robert Kourist ${ }^{1^{*}}$

\begin{abstract}
Background: Global resource depletion poses a dramatic threat to our society and creates a strong demand for alternative resources that do not compete with the production of food. Meeting this challenge requires a thorough rethinking of all steps of the value chain regarding their sustainability resource demand and the possibility to substitute current, petrol-based supply-chains with renewable resources. This regards also the production of catalysts for chemical synthesis. Phototrophic microorganisms have attracted considerable attention as a biomanufacturing platform for the sustainable production of chemicals and biofuels. They allow the direct utilization of carbon dioxide and do not compete with food production. Photosynthetic enzyme production of catalysts would be a sustainable supply of these important components of the biotechnological and chemical industries. This paper focuses on the usefulness of recombinant cyanobacteria for the photosynthetic expression of enantioselective catalysts. As a proof of concept, we used the cyanobacterium Synechocystis sp. PCC 6803 for the heterologous expression of two highly enantioselective enzymes.

Results: We investigated the expression yield and the usefulness of cyanobacterial cell extracts for conducting stereoselective reactions. The cyanobacterial enzyme expression achieved protein yields of $3 \%$ of total soluble protein (\%TSP) while the expression in E. coli yielded 6-8\% TSP. Cell-free extracts from a recombinant strain expressing the recombinant esterase ST0071 from the thermophilic organism Sulfolobus tokodai ST0071 and arylmalonate decarboxylase from Bordetella bronchiseptica showed excellent enantioselectivity (>99\% ee) and yield (>91\%) in the desymmetrisation of prochiral malonates.

Conclusions: We were able to present the proof-of-concept of photoautotrophic enzyme expression as a viable alternative to heterotrophic expression hosts. Our results show that the introduction of foreign genes is straightforward. Cell components from Synechocystis did not interfere with the stereoselective transformations, underlining the usability of photoautotrophic organisms for the production of enzymes. Given the considerable commercial value of recombinant biocatalysts, cyanobacterial enzyme expression has thus the potential to complement existing approaches to use phototrophic organisms for the production of chemicals and biofuels.
\end{abstract}

Keywords: Enzyme expression, Sustainability, Photosynthesis, Enantioselectivity, Biocatalysis

\footnotetext{
*Correspondence: Marc.M.Nowaczyk@rub.de; Robert.Kourist@rub.de

²Department of Biosciences and Informatics, Keio University, 3-14-1 Hiyoshi,

Yokohama 223-8522, Japan

1Junior Research Group for Microbial Biotechnology, Ruhr-Universität

Bochum, Universitätsstr. 150, 44780 Bochum, Germany

Full list of author information is available at the end of the article
} 


\section{Background}

Global resource depletion poses a dramatic threat to our society. Fossil-based resources will run out in the next decades, and alternative resources that do not compete with the production of food have to be identified. Meeting this challenge requires a thorough rethinking of all steps of the value chain, particularly regarding their resource demand and the possibility to substitute current, petrol-based supply-chains by renewable resources. This also regards the source of catalysts for the transformation of chemicals. Because biocatalysts function under very mild reaction conditions, they serve as very sustainable catalysts [1]. Their high selectivity makes it possible to shorten reaction routes and has led to numerous applications for the environmentally friendly synthesis of fine chemicals and pharmaceuticals [2]. The market for industrial enzymes grew nearly with double-digit pace from 2003 - in 2009 it reached $\$ 5.1$ billion [3]. Enzyme production has relied so far mostly on heterotrophic expression systems that require substantial amounts of agriculturally produced nutrients. Direct utilization of photons by photoautotrophic enzyme production (Figure 1) allows the production of catalysts from little more than carbon dioxide, light and water [4]. Photoautotrophic microorganisms have the ability to utilize $15 \%$ of absorbed light for biomass formation [5]. Given the large amount of produced enzymes, photoautotrophic enzyme production has a very large potential to reduce the demand for reduced carbon sources as

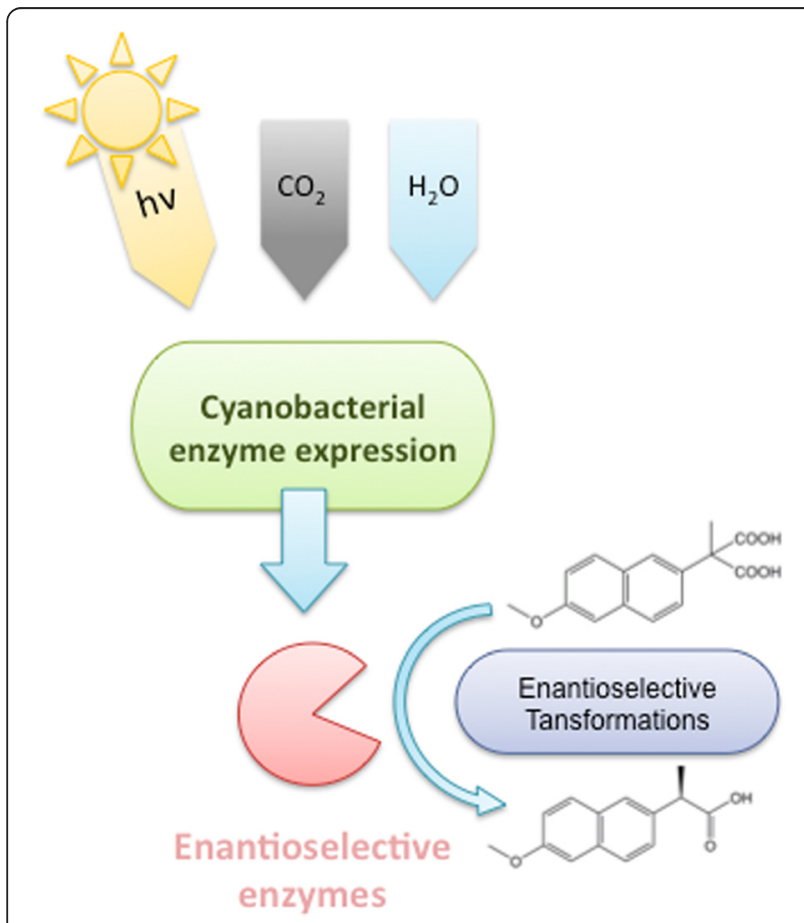

Figure 1 Cyanobacterial enzyme expression of enantioselective enzymes is a sustainable source of biocatalysts for the chemical industry. growth media, which in turn leads to considerably savings of fossil resources needed for the agricultural production of these media. Synthetic biology has emerged as a successful strategy for the expansion of the product spectrum and has already achieved the synthesis of 17 platform chemicals like 1-butanol and ethyle in phototrophic microorganisms [6,7]. Cyanobacterial catalyst production would be a step further towards a phototrophic biorefinery.

Wild-type cyanobacteria have shown high selectivity in whole-cell biotransformation, where the abundant supply of reduction equivalents from photosynthesis represents an additional advantage over heterotrophic systems [8]. Recent works show the feasibility and cost-effectiveness of the expression of therapeutic proteins and industrial enzymes such as xylanases and phytases in microalgae. Typical yields are in the range of $0.1-3 \%$ of the total soluble protein, but also yields up to $21 \%$ TSP have been achieved [4]. In contrast to eukaryotic microalgae [9], Synechocystis sp. PCC 6803 (Synechocystis) and other cyanobacteria are easy to manipulate $[10,11]$, which makes the introduction of foreign genes straightforward. Cyanobacteria have been successfully cultivated in closed bioreactors and open ponds at low cost. The absence of a reduced carbon source also reduces the risk of contamination by bacteria or fungi. This simplifies the scaling significantly. Moreover, existing approaches for the production of biofuels and chemicals created a sophisticated technology for the large-scale cultivation of photoautotrophic bacteria. Photoautotrophic enzyme production thus has a high potential for biocatalytic applications. However, to our knowledge, cyanobacterial cell-extracts have not been applied for in vitro biocatalysis so far.

As a proof of concept, we applied cyanobacterial cellextracts harbouring recombinant enzymes for the desymmetrization of malonic acids, a widely used reaction for the production of optically pure building blocks and pharmaceuticals [12,13]. Thermostable esterase ST0071 from the thermophilic archaeon Sulfolobus tokodaii shows high enantioselectivity in the desymmetrization of malonic acid diesters $[14,15]$. As ST0071 has inverse enantiopreference to porcine liver esterase, it complements this widely applied enzyme as an enantioselective catalyst [14]. Interestingly, ST0071 also possesses a promiscuitive, stereoslective decarboxylase activity [15]. While ST0071 produces optically active half esters, arylmalonate decarboxylase (AMDase) from Bordetella bronchiseptica catalyses the conversion of prochiral malonic acids to enantiomerically pure arylaliphatic carboxylic acids.

\section{Results}

\section{Establishment of expression system}

The fact that Synechocystis contains up to 200 copies of its genome [16] and that foreign DNA is taken up spontaneously prompted us to use stable genome integration 
via homologues recombination for enzyme expression. The corresponding plasmids are compatible to a set of E. coli expression vectors that have been created in a previous study [17], thus allowing easy exchange of genes for expression in different host organisms. To facilitate the quantification of the enzymes in crude extracts, we created fusion proteins with super-folder GFP [18], an enhanced derivative of the well-known green fluorescent protein. The strong psbA2 promoter [19] was chosen to control expression of recombinant genes in cyanobacteria (Figure 2). As the construct contains a gene that mediates chloramphenicol resistance, raising the concentration of this antibiotic in a subsequent cultivation of 1-2 weeks increased the copy number of the gene by segregation. Thus, the whole process from cloning to segregation took 4-6 weeks. PCR experiments confirmed the successful integration of the genes ST0071 and AMDase into the Synechocystis genome (Figure 3).

The Synechocystis strain bearing the recombinant gene ST0071 was cultivated in $4 \mathrm{~L}$ scale under constant ventilation with $\mathrm{CO}_{2}$ enriched air $\left(5 \% \mathrm{CO}_{2}\right)$ using a light intensity of $300 \mu \mathrm{mol}$ of photons $\mathrm{m}^{-2} \mathrm{~s}^{-1}$. Expression of the recombinant enzyme did not impair the growth rate (Figure 4). After four days of cultivation, cells were disrupted using glass beads. Enzyme concentration in crude extracts was determined by GFP fluorescence based on addition of a GFP standard (standard addition method). Esterase expression was visualised by activity staining (Figure 5) quantified by measuring the activity in the hydrolysis of p-nitrophenyl butyrate. Cyanobacterial cell extracts showed some background hydrolytic activity, which could be suppressed by a heat shock of $20 \mathrm{~min}$. at $70^{\circ} \mathrm{C}$. The light-inducible promoter psbA2 has been reported to increase enzyme expression at cultivation under highlight conditions [20]. Indeed, changing the light intensity from $60 \mu \mathrm{mol}$ photons $\mathrm{m}^{-2} \mathrm{~s}^{-1}$ to $300 \mu \mathrm{mol} \mathrm{m} \mathrm{m}^{-2}$ increased the activity from $70 \mathrm{U} \mathrm{g}_{\mathrm{CDW}}{ }^{-1}$ to $108 \mathrm{U} \mathrm{g}_{\mathrm{CDW}}{ }^{-1}$. Under best conditions, determination of the protein concentration of the esterase in the cell-free extract showed $8.2 \mathrm{mg} \mathrm{L}^{-1}$ or $3.9 \%$ of total soluble protein (TSP). This means that the capacity of Synechocystis for the production of heterologous proteins is about two thirds of that of E. coli with 6.4\% TSP (Table 1). This is a comparatively high expression yield in a phototrophic microorganism [4].

The resulting specific activity of $50 \mathrm{U} \mathrm{mg}^{-1}$ in cell free extracts of Synechocystis is in excellent agreement with the specific activity of $60 \mathrm{U} \mathrm{mg}^{-1}$ after cultivation in $E$. coli. Given the lower cell-densities that can be achieved with cyanobacteria in comparison to $E$. coli, we were pleased to find a volumetric activity of or $411 \mathrm{U} \mathrm{L}^{-1}$, which is $25 \%$ of the unit yield of the heterotrophic expression. Despite this encouraging result, the low growth rate of the cyanobacteria is still a considerable bottleneck. A cultivation batch of Synechocystis takes about 4 days, while cultivation in E. coli can be performed within 6 hours. The slow growth results in a relative space-time yield of only $1.6 \%$.

In order to investigate the effectiveness of the cyanobacterial expression system for biocatalytic reactions, we applied crude extracts bearing thermostable esterase ST0071 for the desymmetrization of phenyl methyl diethyl malonate 1 (Figure 6), esterase ST0071 showed a remarkably high selectivity and produced optically pure $(S)$-halfester with $99 \% \mathrm{ee}(S)$ and $>99 \%$ conversion (Table 2). The high selectivity of $99 \% \mathrm{ee}(S)$ was also confirmed using His-tag purified enzyme from the Synechocystis cultivation. A control experiment using a strain without the esterase did not show any measurable activity in the hydrolysis of $\mathbf{1}$, and heat treatment of the cell-free extract was not necessary.

Arylmalonate decarboxylase was introduced with a similar strategy as fusion protein with sfGFP into the neutral site slr1608 of the Synechocystis genome. After confirmation of complete segregation, the expression of the AMDase under highlight conditions yielded $335 \mathrm{U} \mathrm{L}^{-1}$ in the decarboxylation of phenylmalonate and a protein concentration of $8.0 \mathrm{mg} \mathrm{L}^{-1}$. Similar to the esterase expression, this is about one fourth of the yield in E. coli (33.2 $\mathrm{mg} \mathrm{L}^{-1}$ ) and corresponded to $3.0 \%$ TSP in comparison to $7.8 \%$ TSP in E. coli. His-tag purification yielded $5.7 \mathrm{mg} \mathrm{L}^{-1}$, which is a purification yield of $68 \%$. Cell free extracts containing AMDase converted prochiral malonates to optically pure naproxen $\mathbf{4 a}$ and flurbiprofen $\mathbf{4 b}$ with very high enantioselectivity (Figure 7 , Table 2). The high selectivity towards $\mathbf{3 a}$ and $\mathbf{3 b}$ was confirmed using

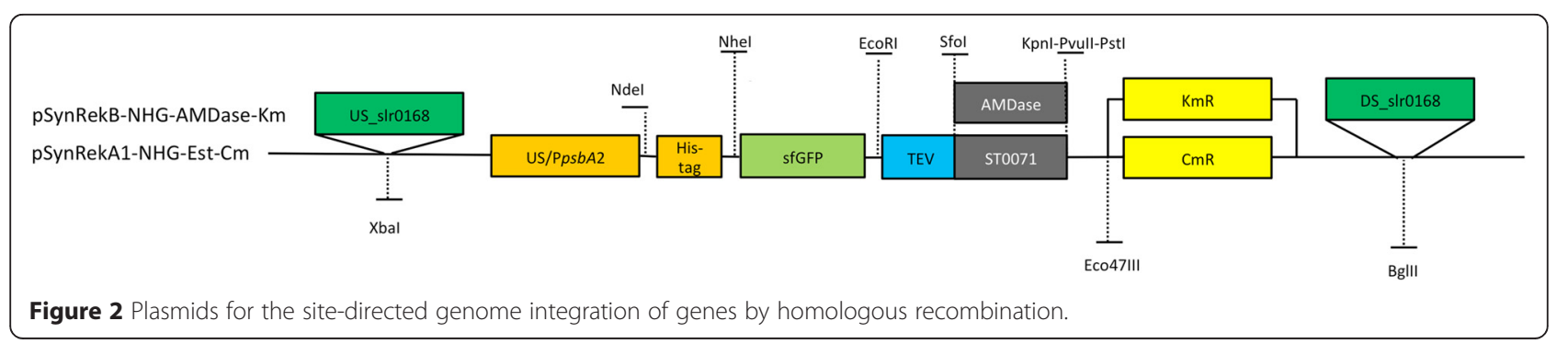





Figure 3 Confirmation of successful genome integration of $\mathbf{a})$ the ST0071 gene and $\mathbf{b}$ ) the AMDase gene by PCR.

purified enzyme. In a control reaction, crude extracts without AMDase did not show any decarboxylating activity. The example of AMDase shows that the approach is thus applicable also with enzymes from mesophilic organisms. In a preparative-scale reaction batch, Synechocystis cell-free extract produced $76 \mathrm{mg}$ optically pure $(R)$-naproxen in very good yield and excellent optical purity $(91 \%$, >99\% ee).

\section{Discussion}

Our findings unveil the proof-of-concept in using cyanobacteria for producing enantioselective enzymes using $\mathrm{CO}_{2}$, water and light. The results show that Synechocystis is capable to produce recombinant enzymes in concentrations of $8-9 \mathrm{mg} \mathrm{L}^{-1}$ and $3-4 \%$ TSP, which is significantly higher than enzyme yields reported for microalgae [4]. It is an important observation that cyanobacterial cell components do not interfere with the enantioselective reactions, which is an important prerequisite for commercial applications. For practical applications it should also be emphasized that the manipulation of Synechocystis is straightforward and can be conducted in 4-6 weeks.

Compared to E. coli, the cyanobacterial enzyme expression achieves a specific activity of $25 \%$. For an initial experiment in comparison to a well-established expression system, this is a very encouraging result, due to the inherent sustainability to produce the biomass directly from carbon dioxide and light instead from media that require the detour of agricultural production.

Volumetric enzyme yields of up to $25 \%$ of $E$. coli show that the water demand, a frequent concern in the

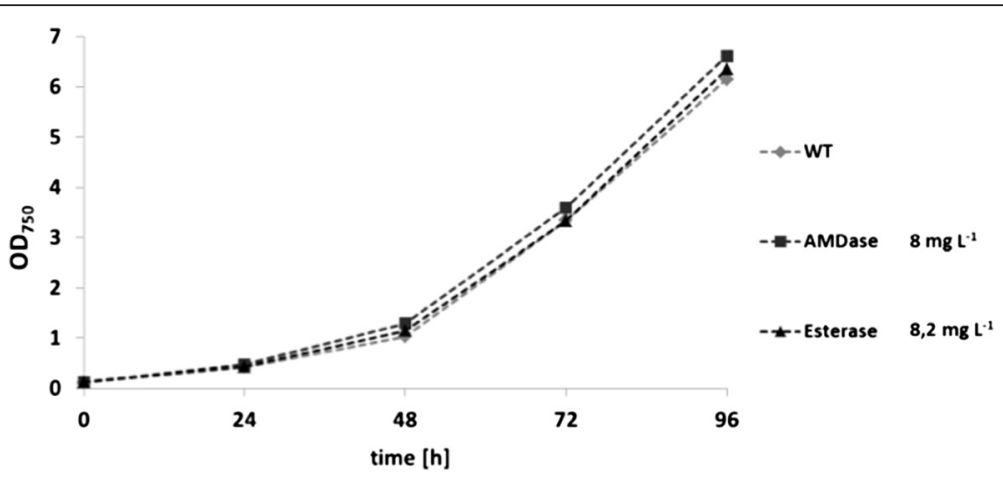

Figure 4 Cultivation in $5 \mathrm{~L}$ scale of Synechocystis wild type and recombinant strains with protein yields after $96 \mathrm{~h}$. 


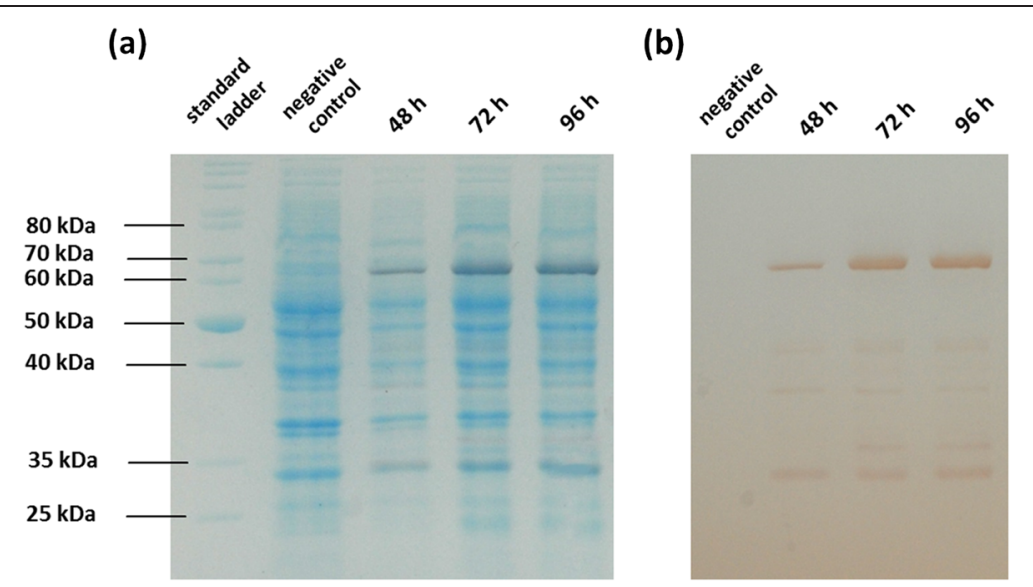

Figure 5 Functional expression of esterase ST0071 in Synechocystis sp. 6803. (a) SDS-PAGE of a functional expression of the sfGFP-fusion protein of esterase ST0071 (64 kD) in Synechocystis sp. PCC 6803 (b) Selective activity staining using a-naphthylacetate and Fast Red [29]. Cultures were grown in BG-11 media [28] in shake flasks and tubes at $30^{\circ} \mathrm{C}$ under a light strength of $300 \mu \mathrm{mol}$ photons $\mathrm{m}^{-2} \mathrm{~s}^{-1}$ under an atmosphere containing $5 \%$ of $\mathrm{CO}_{2}$.

application of photoautotrophic organisms, will not be much higher than with heterotrophic organisms. However, at this stage of engineering, the slow growth and the demand for freshwater hinder potential commercial applications. Continuous cultivation systems have a potential to increase space-time-yields. For the time being, Synechocystis sp. offers the advantage of the availability of suitable genetic tools for the introduction and functional expression of heterologous genes. The development of tunable promoters and other tools is undergoing a rapid progress $[10,11]$. Fast-growing and salt-water tolerant strains $[6,7]$ are expected to alleviate the slow growth in a longer perspective and will pave the way for a cyanobacterial biomanufacturing platform using waste-water or seawater. The demand for these strains has been recognized, and on-going research $[10,11]$ will make these strains amenable for genetic manipulation and facilitate their application for recombinant enzyme production.

Cell-free-extracts from Synechocystis contain similar amounts of biocatalysts than E. coli. This is significantly different to approaches that aim to utilize Synechocystis for chemical production, where yields are several magnitudes lower than in E. coli or Synechocystis. Cyanobacteria have been demonstrated to be very proficient whole-cell biocatalysts for the biotransformation of organic compounds [8]. Our results show that recombinant cyano- bacterial strains are highly useful expression systems for the environmentally-friendly production of enzymes.

The excellent enantioselectivities in the synthesis of the optically pure phenyl methyl malonate ethyl ester $(S)$ - 2a and the optically pure profens naproxen and flurbiprofen demonstrate the feasibility of the application of cyanobacterial cell-free extracts for catalytic purposes. The cyanobacterial components do not interfere with the reaction, which is an important prerquisite for commercial applications. Expansion of this approach to the recombinant expression of oxidoreductases will be particularly interesting, as cyanobacteria can also supply NADPH as cofactor, resulting in very proficient whole-cell biocatalysts for the biotransformation of organic compounds [8]. The successful production of enzymes in phototrophic organisms is an important step towards a photoautotrophic biorefinery, in which cyanobacteria and microalgae convert carbon dioxide, light and water to useful chemicals such as bio-hydrogen [21], terpenes [22], carotinoids [19] and fatty acids [23]. Photoautotrophic enzyme production will be a sustainable strategy to provide biocatalysts for this visionary biorefinery. Enzyme production can use the infrastructure and the facilities of the main process, which creates further synergistic effects. A prominent example for the on-site production of biocatalysts in industrial scale is the synthesis of cellulolytic enzymes in brewer's yeast [24-26].

Table 1 Comparison of the functional expression of sfGFP-Est ST0071 in Synechocystis sp. PCC 6803 and E. coli

\begin{tabular}{|c|c|c|c|c|c|}
\hline & $\begin{array}{l}\text { Volumetric activity }{ }^{[1]} \\
\mathrm{U} \mathrm{L}^{-1}\end{array}$ & $\begin{array}{l}\text { Protein yield }{ }^{[2]} \\
\mathrm{mg} \mathrm{L}^{-1}\end{array}$ & $\begin{array}{l}\text { Specific activity } \\
\mathrm{U} \mathrm{mg}^{-1}\end{array}$ & $\begin{array}{l}\text { Space time yield } \\
U L^{-1} h^{-1}\end{array}$ & $\begin{array}{l}\text { Specific activity } \\
U^{\bullet} g_{\mathrm{CDW}^{-1}}\end{array}$ \\
\hline Synechocystis USpsbA2 Est & $411 \pm 19$ & $8.2 \pm 2$ & 50 & 4.3 & 108 \\
\hline E. coli pRSET6a His_sfGFP_Est & $1639 \pm 69$ & $27.5 \pm 4.4$ & 60 & 273 & 441 \\
\hline
\end{tabular}

${ }^{[1]}$ Determined in the hydrolysis of para-nitrophenyl butyrate; ${ }^{[2]}$ determined by standard-addition-method. 


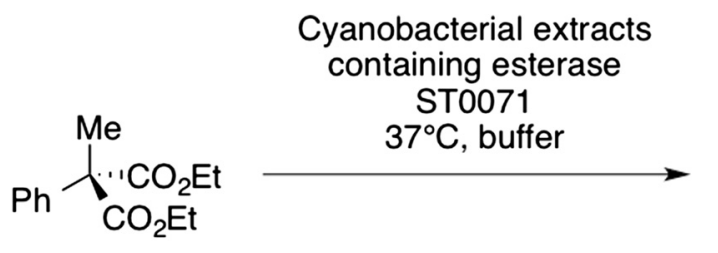

1<smiles>CCOC(=O)C(C)(C(=O)O)c1ccccc1</smiles>

(S)-2

$>99 \%$ conversion $>99 \%$ ee $(S)$

Figure 6 Esterase-catalysed desymmetrization of a prochiral malonic acid ester. Cell lysate from a cultivation Synechocystis sp. sfGFP-ST0071 cell lysate ( $500 \mu \mathrm{L}$ of a $750 \mathrm{~mL}$ cultivation, OD 6.5) was added to a solution of $5 \mathrm{mM}$ phenyl methyl malonate diethyl ester 1 and incubated for $48 \mathrm{~h}$ at $37^{\circ} \mathrm{C}$. The reaction was stopped by addition of $\mathrm{HCl}(200 \mu \mathrm{L}, 2 \mathrm{M})$, extracted twice with methyl tert-butyl ester. The optical purity of (S)-2 was determined using by chiral HPLC.

\section{Conclusions}

We were able to present the proof-of-concept of photoautotrophic enzyme expression as a viable alternative to heterotrophic expression hosts. Cell-free extracts from Synechocystis were successfully applied as catalysts for the asymmetric synthesis in high conversion and excellent enantioselectivity. Our results show that the introduction of foreign genes is straightforward and that cell components do not interfere with enzymatic reactions. Photoautotrophic enzyme expression achieves yields of about $25 \%$ of the established heterotrophic system $E$. coli. Nevertheless, cyanobacterial biomass stems directly from photosynthesis, while heterotrophic organisms require the detour of agricultural plant cultivation, harvest and processing. The great demand of an enzyme market of $\$ 5.1$ billion [3] underlines the great potential of photosynthetic biocatalyst production for energy and fossil resources savings.

\section{Methods}

\section{General}

All chemicals were purchased from Sigma-Aldrich (Steinheim, Germany). Arylmalonic acids $\mathbf{3 b}$, 3c and $\mathbf{3 d}$ were kindly provided by Chiracon $\mathrm{GmbH}$ (Teltow, Germany). Fluorescence and absorption were measured with a FLUOstar Omega Fluorimeter (BMG Labtech GmbH Ortenberg, Germany) DNA samples were sequenced by the DNA sequencing service of the department of biochemistry at Ruhr-University Bochum. Kits for ligation, DNA isolation and restriction were purchased at Fermentas (St. Leon-Rot, Germany). Enzyme affinity purification was done using a $1 \mathrm{~mL}$ His Pure Ni-NTA column (Pierce Biotechnology Rockford, USA). Chiral GC analyses were carried out using the chiral column FS-Hydrodex- $\beta$-6TBDM [heptakis-(2,3-di-O-methyl-6O- $t$-butyldimethylsilyl)- $\beta$-cyclodextrin] (Macherey Nagel, Germany) on a GC-FID-2010 (Shimadzu, Japan). Retention times for $\mathbf{2 b}\left(160^{\circ} \mathrm{C}\right)$ were $31.5 \mathrm{~min}(S)$ and $32.3 \mathrm{~min}$ $(R)$ for $2 \mathbf{c}\left(170^{\circ} \mathrm{C}\right) 12.9 \mathrm{~min}(S)$ and $14.4 \mathrm{~min}(R)$. The elution order was identified using commercial $(S)$-naproxen (TCI Chemicals, Japan). Chiral HPLC analyses were carried out using the column CHIRALCEL OD-H (Daicel, Osaka, Japan) on a L-7110 HPLC device (Hitachi High Tech, Tokyo, Japan) using n-hexane/i-propanol/trifluor acetic acid (98:2:0.5). With a flow rate of $0.5 \mathrm{~mL}$, the two enantiomers of phenyl methyl malonic acid ethyl ester $\mathbf{2 a}$ eluted with $55 \mathrm{~min}(S)$ and $65 \mathrm{~min}(R)$.

\section{Expression of GFP-esterase and GFP-AMDase fusion proteins in E. coli}

The vector pET100 ST0071 containing the native gene of esterase ST0071 [12] and pBAD_AMDase containing a codon optimized gene of AMDase from Bordetella bronchiseptica pBAD[22] were kindly provided by Kenji Miyamoto, Keio University (Japan). For overexpression of both proteins as fusion proteins with an $\mathrm{N}$-terminal His6-sfGFP tag, genes were amplified by PCR using the oligonucleotides GGCGCCGCTAGCATAGACCCTA AAATTA or GCGAATTCGCG-GCGCGATGGGCCAA ATGCAACAGG (forward primer), GATG-GTACCTTA

Table 2 Biocatalysis experiments using photoautotrophically produced enzymes

\begin{tabular}{llllll}
\hline Biocatalyst & Substrate & Product & Time & Conversion & $\begin{array}{l}\text { Enantiomeric excess } \\
{[\mathbf{h}]}\end{array}$ \\
\hline Est ST0071 (cell-free-extract) & $\mathbf{1 a}$ & $(S)-\mathbf{2 a}$ & 180 & $>99 \%^{[\mathrm{a}]}$ & $>99 \%^{[\mathrm{a}]}$ \\
AMDase (cell-free-extract) & $\mathbf{3 b}$ & $(R)-\mathbf{4 b}$ & 2 & $>99 \%^{[\mathrm{b}]}$ & $>99 \%^{[\mathrm{b}]}$ \\
AMDase (cell-free-extract) & $\mathbf{3 c}$ & $(R)-\mathbf{4 c}$ & 2 & $>99 \%^{[\mathrm{b}]}$ & $99 \%^{[\mathrm{b}]}$ \\
\hline
\end{tabular}

${ }^{[\mathrm{a}]}$ Determined by chiral HPLC; ${ }^{[\mathrm{b}]}$ Determined by chiral GC. 
a)<smiles>CC(Br)(C(=O)O)C(=O)O</smiles>

3<smiles>COc1ccc2cc(C)ccc2c1</smiles>

4a: Naproxen
$>99 \%$ conversion $>99 \%$ ee $(R)$

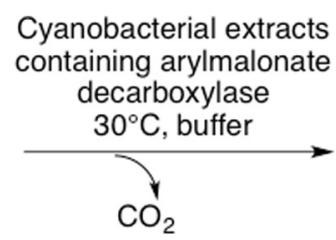

Cyanobacterial extracts

containing arylmalonate decarboxylase $\mathrm{CO}_{2}$<smiles>Cc1ccc(-c2ccccc2)c(F)c1</smiles>

4b: Flurbiprofen $>99 \%$ conversion $>99 \%$ ee $(R)$ b)<smiles>CC(Br)C(=O)O</smiles>

$(R)-4$

Figure 7 Arylmalonate decarboxylase-catalyzed desymmetrization of prochiral malonic acids. a) Desymmetrization of prochiral malonic acids 3a and $4 \mathrm{~b}$ at $30^{\circ} \mathrm{C}$ using cell lysates from a cultivation of Synechocystis sp. sfGFP-AMDase. b) GC-chromatogram of optically pure (R)-4a (grey) and a racemic standard (light grey).

TTTGTAGAGCTCTTTTCC or GCCTGCAGTTAGCTGCCACCGGACTCAT (reverse primer) and cloned into the pNHIS-GFP-TEV plasmid [19] via the SfoI and KpnI restriction enzyme sites. The resulting plasmids pNHGEst and pNHG-Amd were used for transformation of E. coli overexpression C43 cell (Lucigen) and protein expression was performed according to literature [17]. For the determination of dry cell weight (DCW), $15 \mathrm{~mL}$ of the culture supernatant was added in triplicate to pre-weighed reaction tubes and centrifuged for $4 \mathrm{~min}$ at $13000 \mathrm{rpm}$ and $4{ }^{\circ} \mathrm{C}$. After a subsequent washing step with $0.9 \%(\mathrm{w} / \mathrm{v})$ $\mathrm{NaCl}$, cell pellets were dried until constant mass at $60^{\circ} \mathrm{C}$ for at least 4 days.

\section{Construction of plasmids for expression of GFP fusion proteins in synechocystis}

For heterologous expression of the GFP-esterase fusion in Synechocystis under the control of the strong psbA2 promoter [19], the plasmid pSynRekA1-NHG-Est-Cm was constructed, that allows replacement of the native psbA2 gene by homologous recombination. A 500 bp upstream region of psbA2 gene was amplified by PCR with the primer pair GATCTAGACAGAATCCTTGCC CAGATGC and CGTTGTCATATGGTTATAATTCC and cloned into the pNHG-Est plasmid via the XbaI and NdeI restriction enzyme sites. In the last step an antibiotic resistance cassette that is conferring resistance to chloramphenicol, was inserted into the BamHI site of the plasmid.

For expression of the GFP-AMDase fusion in Synechocystis, the plasmid pSynRekB-NHG-AMDase-Km was generated. This allows integration at the neutral site of slr0168 [27] and expression under the control of the psbA2 promoter. The 800 bp upstream region of slr0168 was amplified by PCR with the primer pair TCTAGA GAGTTATTGGCGATCGAAGC and CTAGCTTAGG GGGTGTATTGAATAGTCATAG and cloned into the XbaI site of an intermediate pSynRekA-NHG-Est construct without the $\mathrm{Cm}$ cassette. The $800 \mathrm{bp}$ downstream region of slr0168 was amplified by PCR with the primer pair GGATCCAGCGCTTGGCATCAGCCACAGCAC AAAC and AGATCTCACCACCTTGGGCTTGATGC and cloned into the BglII site. In the next step a kanamycin resistance cassette was cloned into an Eco47III site that was introduced by the forward primer used for PCR amplification of the downstream fragment. Finally, the coding sequence of the Esterase was replaced by that of the AMDase via the SfoI and KpnI sites.

\section{Transformation of Synechocystis}

Wild type cells of $1 \mathrm{~mL}$ culture $(\mathrm{OD} 750=2)$ were harvested by centrifugation and resuspended in $100 \mu \mathrm{l}$ fresh BG11 media. Plasmid DNA was added to a final concentration of $0.02 \mu \mathrm{g} \times \mathrm{mL}^{-1}$ and cells were incubated in darkness for $5 \mathrm{~h}$ at $30^{\circ} \mathrm{C}$. After recovery treatment, transformants were incubated another $24 \mathrm{~h}$ at low light conditions $\left(<60 \mu \mathrm{mol}\right.$ photons $\left.\mathrm{m}^{-2} \times \mathrm{s}^{-1}\right)$ and finally spread on BG-11 plates with the corresponding antibiotic chloramphenicol $\left(5 \mu \mathrm{g} \times \mathrm{mL}^{-1}\right)$ or kanamycin $\left(40 \mu \mathrm{g} \times \mathrm{mL}^{-1}\right)$. In order to promote full segregation of the mutant allele, the selective pressure was increased gradually to a final concentration of $50 \mu \mathrm{g} \times \mathrm{mL}^{-1}$ 
(chloramphenicol) and $150 \mu \mathrm{g} \times \mathrm{mL}^{-1}$ (kanamycin). Successful integration was confirmed by PCR.

\section{Synechocystis culture conditions and preparation of cell extracts}

Synechocystis strains were cultivated in BG-11 media (see also the electronic supplementary information) [28] in shake flasks and tubes at $30^{\circ} \mathrm{C}$ under varying light conditions from $60 \mu \mathrm{mol}$ photons $\mathrm{m}^{-2} \mathrm{~s}^{-1}$ up to $300 \mu \mathrm{mol}$ photons $\mathrm{m}^{-2} \mathrm{~s}^{-1}$ under an atmosphere containing $5 \%$ of $\mathrm{CO}_{2}$. For functional expression of esterase and AMDase, the media were supplemented with chloramphenicol $\left(50 \mu \mathrm{g} \mathrm{mL}^{-1}\right)$ or kanamycine $\left(150 \mu \mathrm{g} \mathrm{mL}^{-1}\right)$, respectively.

For preparation of raw extracts, cells were harvested by centrifugation $\left(20 \mathrm{~min}, 4^{\circ} \mathrm{C}, 8,000 \mathrm{rpm}\right)$ and washed with buffer. Cell disruption was performed with a Precellis Homogenizer (PEQLAB Biotechnologie $\mathrm{GmbH}$, Erlangen, Germany) in precooled $2 \mathrm{~mL}$ screw-cap tubes containing $750 \mu \mathrm{l}$ glass beads $(0.1-2 \mathrm{~mm}$ diameter) with two pulses of 30 s with 6800 oscillations per minute. The supernatant was transferred to another tube and centrifuged in order to remove cell debris $(67,000 \mathrm{~g}, 40 \mathrm{~min}$. $\left.4^{\circ} \mathrm{C}\right)$. After cell disruption by French press, this step can alternatively conducted with $10,000 \mathrm{~g}$ for $30 \mathrm{~min}$. and $4^{\circ} \mathrm{C}$. After SDS-gel electrophoresis, the gel was first activity-stained with $\alpha$-naphthylacetate and Fast Red [29] followed by Coomassie brilliant blue staining.

\section{Fluorescence standard addition for protein determination}

As cyanobacterial cell extracts showed considerable background fluorescence, standard addition was chosen to quantify sfGFP fusion proteins. Purified sfGFP fusion esterase or AMDase were added as standard directly to cyanobacterial crude extract. The optimal size of each addition was chosen generating a signal 1.5 to 3 times that of the unknown sample. using excitation-/emission-filters at $480-/ 520 \mathrm{~nm}$, respectively. From at least 5 measurements, a line was extrapolated to zero fluorescence, and the endogenous concentration of analyte was determined from the point of intersection with the abscissa. The percentage of purified enzymes of the total soluble protein (TSP) was determined by relating these values to protein concentrations determined with Bradford reagent.

\section{Biocatalysis experiments}

Esterase activity was determined in triplicates spectrophotometrically by hydrolysis of $p$-nitrophenyl acetate (10 $\mathrm{mM}$ in DMSO) in sodium phosphate buffer $(10 \mathrm{mM}$, $\mathrm{pH}$ 7.4). $p$-Nitrophenol released was quantified at $410 \mathrm{~nm}\left(\varepsilon=15.1^{*} 10^{3} \mathrm{M}^{-1} \mathrm{~cm}^{-1}\right)$. One Unit (U) of activity was defined as the amount of enzyme releasing $1 \mu \mathrm{mol}$ $p$-nitrophenol per min under assay conditions. For desymmetrization experiments, cell lysate from a cultivation Synechocystis sp. sfGFP-ST0071 cell lysate $(500 \mu \mathrm{L}$ of a $750 \mathrm{~mL}$ cultivation, OD 6.5) was added to a solution of $5 \mathrm{mM}$ phenyl methyl malonate diethyl ester 1 and incubated for $48 \mathrm{~h}$ at $37^{\circ} \mathrm{C}$. The reaction was stopped by addition of $\mathrm{HCl}(200 \mu \mathrm{L}, 2 \mathrm{M})$, extracted twice with methyl tert butyl ester. The optical purity of (S)-2 was determined using a Chiracell OD-H column on an HPLCdevice (Shimadzu, Japan) with a mixture of $n$-hexane (97\%) and iso-propanol (3\%) as mobile phase.

\section{Preparative scale AMDase-catalyzed asymmetrization}

Synechocystis sp. sfGFP-AMDase cell lysate $(35 \mathrm{~mL}$ of a $750 \mathrm{~mL}$ cultivation, OD 6.5) was added to a stirred solution of $5 \mathrm{mM}$ 2-(6-ethoxy-2-naphthyl) malonic acid $(100 \mathrm{mg}, 0.36 \mathrm{mmol})$ in tris buffer $(50 \mathrm{mM}, 300 \mathrm{mM}$ $\mathrm{NaCl}, \mathrm{pH} 7.5)$ to a total volume of $73 \mathrm{~mL}$, respectively. The reaction mixture was stirred for 4 hours at $30^{\circ} \mathrm{C}$ and stopped by addition of $\mathrm{HCl}(35 \mathrm{~mL}, 2 \mathrm{M})$. The reaction mixture was extracted three times with methyl tertbutyl ether $(100 \mathrm{~mL})$. The organic layers were combined and washed with brine $(2 \times 50 \mathrm{~mL})$, and dried over anhydrous $\mathrm{MgSO}_{4}$. The solvent was removed under reduced pressure to yield optically pure $(R)$-2-(6-ethoxy-2naphthyl) propionic acid $((R)-\mathbf{4 b})$ as yellowish powder (76.2 mg, $0.33 \mathrm{mmol}, 91.7 \%$, >99\% ee). 1H NMR: $\mathrm{d}=1.59(3 \mathrm{H}, \mathrm{d}, \mathrm{CH} 3), 3.87(1 \mathrm{H}, \mathrm{q}, \mathrm{CH}), 3.90(3 \mathrm{H}, \mathrm{q}$, $\mathrm{OCH} 3), 7.09,7.71(6 \mathrm{H}, \mathrm{m}, \mathrm{Ar}-\mathrm{H})$; 13C NMR: $\mathrm{d}=18.0(\mathrm{~s})$, $45.1(\mathrm{~s}), 55.3(\mathrm{~s}), 105.5(\mathrm{~s}), 119.0(\mathrm{~s}), 126.1(\mathrm{~s}), 127.3(\mathrm{~s})$, $128.8(\mathrm{~s}), 129.3(\mathrm{~s}), 133.8(\mathrm{~s}), 134.9(\mathrm{~s}), 157.7(\mathrm{~s}), 179.6(\mathrm{~s})$.

\section{Competing interests}

The authors declare that they have no competing interests.

\section{Authors' contributions}

$\mathrm{MB}, \mathrm{KK}, \mathrm{ND}$ and PL conducted cloning and enzyme expression experiments, $\mathrm{SG}$ and $\mathrm{KI}$ conducted biocatalytic reactions, KM, MN and RK conceived the conceived of the study, and participated in its design and coordination and drafted the manuscript. All authors read and approved the final manuscript.

\section{Acknowledgements}

R.K. and S.G. gratefully acknowledge financial support from the Deutsche Bundesstiftung Umwelt (AZ30818-32). This work was further supported by a grant of the Ruhr-University Bochum ('Rektoratsprogramm') to M.M.N.

\section{Author details}

1Junior Research Group for Microbial Biotechnology, Ruhr-Universität Bochum, Universitätsstr. 150, 44780 Bochum, Germany. ${ }^{2}$ Department of Biosciences and Informatics, Keio University, 3-14-1 Hiyoshi, Yokohama 223-8522, Japan. ${ }^{3}$ Chair for Plant Biochemistry, Ruhr-Universität Bochum, Universitätsstr. 150, 44780 Bochum, Germany.

Received: 4 February 2015 Accepted: 25 March 2015 Published online: 15 April 2015

\section{References}

1. DiCosimo R, McAuliffe J, Poulose AJ, Bohlmann G. Industrial use of immobilized enzymes. Chem Soc Rev. 2013;42:6437-74.

2. Kourist R, Guterl J-K, Miyamoto K, Sieber V. Enzymatic decarboxylation - an emerging reaction for chemicals production from renewable resources. Chem Cat Chem. 2014;6:689-701.

3. Sanchez S, Demain AL. Enzymes and bioconversions of industrial, pharmaceutical, and biotechnological significance. Org Proc Res Devel. 2010;15:224-30. 
4. Rasala B, Mayfield S. Photosynthetic biomanufacturing in green algae; production of recombinant proteins for industrial, nutritional, and medical uses. Photosynth Res. 2014;123:1-13.

5. Wilhelm C, Jakob T. From photons to biomass and biofuels: evaluation of different strategies for the improvement of algal biotechnology based on comparative energy balances. Appl Microbiol Biotechnol. 2011;92:909-19.

6. Nozzi NE, Oliver JW, Atsumi S. Cyanobacteria as a platform for biofuel production. Synth Biol. 2013;1:7.

7. Oliver JK, Atsumi S. Metabolic design for cyanobacterial chemical synthesis. Photosynth Res. 2014;120:249-61.

8. Balcerzak L, Lipok J, Strub D, Lochyński S. Biotransformations of monoterpenes by photoautotrophic microorganisms. J Appl Microbiol. 2014;117:1523-30.

9. Specht E, Miyake-Stoner S, Mayfield S. Micro-algae come of age as a platform for recombinant protein production. Biotechnol Lett. 2010;32:1373-83.

10. Huang H-H, Camsund D, Lindblad P, Heidorn T. Design and characterization of molecular tools for a synthetic biology approach towards developing cyanobacterial biotechnology. Nucl Ac Res. 2010;8:2577-93.

11. Huang $\mathrm{H}-\mathrm{H}$, Lindblad P. Wide-dynamic-range promoters engineered for cyanobacteria. J Biol Eng. 2013;7:10.

12. Kourist R, Domínguez de María P, Miyamoto K. Biocatalytic strategies for the asymmetric synthesis of profens - recent trends and developments. Green Chem. 2011;13:2607-18.

13. Suss $P$, Illner $S$, von Langermann J, Borchert $S$, Bornscheuer UT, Wardenga R, et al. Scale-up of a recombinant pig liver esterase-catalyzed desymmetrization of Dimethyl Cyclohex-4-ene-cis-1, 2-dicarboxylate. Org Proc Res Devel. 2014;18:897-903.

14. Suzuki Y, Miyamoto K, Ohta H. A novel thermostable esterase from the thermoacidophilic archaeon Sulfolobus tokodaii strain 7. FEMS Microbiol Lett. 2004;236:97-102.

15. Wada R, Kumon T, Kourist R, Ohta H, Uemura D, Yoshida S, et al. Thermally driven asymmetric domino reaction catalyzed by a thermostable esterase and its variants. Tetrahedron Lett. 2013;54:1921-3.

16. Griese M, Lange C, Soppa J. Ploidy in cyanobacteria. FEMS Microbiol Lett. 2011;323:124-31.

17. Liauw P, Kannchen D, Gasper R, Dyczmons-Nowaczyk N, Nowaczyk MM, Hofmann E. Cloning, expression, crystallization and preliminary X-ray studies of Psb32 from the thermophilic cyanobacterium Thermosynechococcus elongatus BP-1. Acta Cryst. 2015;71:409-13.

18. Pedelacq JD, Cabantous S, Tran T, Terwilliger TC, Waldo GS. Engineering and characterization of a superfolder green fluorescent protein. Nat Biotechnol. 2006;24:79-88.

19. Lagarde $D$, Beuf $L$, Vermaas W. Increased production of zeaxanthin and other pigments by application of genetic engineering techniques to Synechocystis sp. strain PCC 6803. Appl Env Microbiol. 2000;66:64-72.

20. Lindberg P, Park S, Melis A. Engineering a platform for photosynthetic isoprene production in cyanobacteria, using Synechocystis as the model organism. Metab Eng. 2010;12:70-9.

21. Badura A, Esper B, Ataka K, Grunwald C, Wöll C, Kuhlmann J, et al. Lightdriven water splitting for (Bio-)hydrogen production: photosystem 2 as the central part of a bioelectrochemical device. Photochem Photobiol. 2006;82:1385-90

22. Kiyota H, Okuda Y, Ito M, Hirai MY, Ikeuchi M. Engineering of cyanobacteria for the photosynthetic production of limonene from CO2. J Biotechnol. 2014;185:1-7.

23. Blatti JL, Michaud J, Burkart MD. Engineering fatty acid biosynthesis in microalgae for sustainable biodiesel. Curr Op Chem Biol. 2013;17:496-505.

24. Aga A, Coh CC. Cellulosic ethanol production using a yeast consortium displaying a minicellulosome and $\beta$-glucosidase. Microb Cell Fact. 2013;12:14.

25. Nakashima K, Yamaguchi K, Taniguchi N, Arai S, Yamada R, Katahira S, et al. Direct bioethanol production from cellulose by the combination of cellulase-displaying yeast and ionic liquid pretreatment. Green Chem. 2011;13:2948-53.

26. Yanase S, Yamada R, Kaneko S, Noda H, Hasunuma T, Tanaka T, et al. Ethanol production from cellulosic materials using cellulase-expressing yeast. Biotechnol J. 2010;5:449-55.
27. Wang W, Liu X, Lu X. Engineering cyanobacteria to improve photosynthetic production of alka(e)nes. Biotechnol Biof. 2015;6:69.

28. Rippka R, Herdman M. Division patterns and cellular differentiation in cyanobacteria. Ann Inst Pasteur Microbiol. 1985;136A:33-9.

29. Schmidt M, Henke E, Heinze B, Kourist R, Hidalgo A, Bornscheuer UT. A versatile esterase from Bacillus subtilis: cloning, expression, characterization, and its application in biocatalysis. Biotechnol J. 2007;2:249-53.

\section{Submit your next manuscript to BioMed Central and take full advantage of:}

- Convenient online submission

- Thorough peer review

- No space constraints or color figure charges

- Immediate publication on acceptance

- Inclusion in PubMed, CAS, Scopus and Google Scholar

- Research which is freely available for redistribution 